\title{
PROBLEMATIKA LINIERITAS PENDIDIKAN GURU ANAK USIA DINI \\ (Studi Kasus di Kelompok Bermain Islam Terpadu (KBIT) Al-Ihsaniyah Desa Bangun Galih Kecamatan Kramat Kebupaten Tegal)
}

\author{
Siti Ratnawati, M.Pd.I \\ Ratnawati25971@gmail.com
}

\section{ABSTRAK}

Problem linieritas guru PAUD merupakan hal yang penting bagi pendidik PAUD tak terkecuali yang terjadi di KBIT Al-Ihsaniyah Bangun Galih Kramat Tegal, sebab masih banyak guru yang tidak linier secara kualifikasi akademik sehingga berpengaruh pada pemenuhan standar akademik dan sertifikasi maupun tunjangan profesi lainnya dan perlu dicari solusi pemecahannya. Guru yang sedang menempuh S1 PGPAUD dalam konteks pedagogik memiliki kemampuan yang berbeda dengan guru selain keduanya terutama dalam pemahaman karakteristik peserta didik. Namun demikian dilihat dari capaian profesiomalisme guru, mereka telah mampu: (1) menguasi materi pelajaran (1) menggunakan berbagai permainan yang menarik,(3) memanfaatkan tekonologi, dan (4) mengembangkannya sesuai perkembangan. Beberapa kebijakan dan program dijalankan, di antaranya ialah: (1) melakukan proses seleksi (2) program magang/mengabdi (3) mengikutsertakan pada kegiatan diklat, dan seminar (4) menjalin komunikasi di antara pendidik.

Kata Kunci: Problem, Linieritas, Guru PAUD

\section{ABSTRACT}

The problem of PAUD teacher linearity is an important thing for PAUD educators, including situations at KBIT Al-Ihsaniyah Bangun Galih Kramat Tegal, because there are still many teachers who are not linear in academic qualifications so that, it affects the fulfillment of academic standardization, certification and other professional allowances and need to find the solution. Teachers who are studying S1 PGPAUD in a pedagogical context have 
different abilities from others, it can be seen especially in understanding the characteristics of the students. However, it can be seen from the teachers' achievements of professionalism, they have been able to: (1) master the subject matter (1) use a variety of interesting games, (3) utilize technology, and (4) developing it according to their improvement. Some policies and programs are applied are: (1) the selection process (2) internship program/ serving (3) engage in training activities, and seminars (4) building a good communication between educators.

Keywords: Problem, Linearity, PAUD Teachers

\section{PENDAHULUAN}

Pertumbuhan lembaga PAUD semakin meningkat pesat, namun seperti peningkatan tersebut tidak diimbangi dengan ketersediaan pendidik PAUD dengan lulusan linier di bidangnya seperti S1 PGPAUD atau PIAUD. Sehingga, guru-guru PAUD masih didominasi oleh lulusan SMA dan sarjana-sarjana dari berbagai bidang ilmu.

Kurangnya guru yang sesuai disiplin keilmuannya, banyak lembaga mensiasati kebutuhan pelajarannya dengan memberikan tugas, atau mengangkat guru yang mampu mengajar pada pelajaran tertentu, sebagaimana yang terjadi di Kelompok Bermain Islam Terpadu (KBIT) Al-Ihsaniyah Bangungalih Kramat Tegal.

Di KBIT Al-Ihsaniyah terdapat hanya ada satu guru yang sesuai kualifikasi akademiknya, itupun sedang menempuh S1 PGPAUD dan satu guru yang lulusan Bimbingan Konseling (BK). Sedangkan guru yang lain masih belum sesuai standar kulaifikasi. Hal ini meyebabkan perbedaan dalam memahami karakteristik dan perkembangan peserta didik yang notabene berusia 2,5 tahun sampai 4 tahun, dan mempengaruhi pembelajaran di KBIT Al-Ihsaniyah. Persoalan linieritas tersebut nyatanya menjadi problem yang genting dalam dunia pendidikan anak usia dini dewasa ini.

Secara global, di kecamatan Kramat sendiri terdapat 125 orang guru PAUD, namun yang linier hanya berjumlah 21 guru. Hal ini masih jauh dari ideal, untuk dapat dikatakan sebagai pendidik PAUD. Berbagai upayapun dilakukan oleh pihak KBIT Al-Ihsaniyah, dalam meminimalisir kelemahan kualifikasi akademik guru-guru di KBIT Al-Ihsaniyah. 
Munculnya problem tentang linieritas guru di KBIT Al-Ihsaniyah maupun pada lembaga Pendidikan Anak Usia Dini secara umum, secepatnya harus segera dicarikan solusi pemecahannya.

Melalui artikel "Problematika Linieritas Pendidikan Guru Anak Usia Dini (Studi Kasus di Kelompok Bermain Islam Terpadu (KBIT) Al-Ihsaniyah Desa Bangun Galih Kecamatan Kramat Kebupaten Tegal", penulis berharap bisa mengisi kekosongan yang mungkin ada celah sebagai salah satu solusi dari berbagai problem linieritas guru pendidikan anak usia dini.

\section{LINIERITAS GURU PENDIDIKAN ANAK USIA DINI}

Guru Pendidikan Anak Usia Dini (PAUD) merupakan pendidik yang bertugas di berbagai jenis layanan PAUD baik pada jalur pendidikan formal maupun non-formal, seperti TK/RA/BA, KB, TPA dan bentuk lainnya yang sederajat. Pendidikan dalam konteks ini adalah setiap orang yang melakukan bimbingan, pembinaan, dan pengasuhan terhadap anak usia dini yang diwujudkan melalui proses pembelajaran yang direncanakan. ${ }^{1}$

Pendidikan anak usia dini (PAUD) merupakan salah satu bentuk penyelenggaraan yang menitik beratkan pada peletakan dasar ke arah pertumbuhan dan perkembangan fisik (koordinasi motorik halus dan kasar), kecerdasan (daya pikir, daya cipta, kecerdasan emosi, dan kecerdasan spiritual), sosio-emosional (sikap perilaku serta agama), bahasa dan komunikasi. ${ }^{2}$

Dalam Peraturan Pemerintah No. 19 tahun 2005 pasal 28, ayat 3 disebutkan bahwa, kompetensi guru sebagai agen pembelajaran pada jenjang pendidikan dasar dan menengah serta pendidikan anak usia dini meliputi; (1) kompetensi pedagogik, (2) kompetensi kepribadian, (3) kompetensi profesional, dan (4) kompetensi sosial.

Kata Linieritas berasal kata Line yang berarti garis, garisan, merk, tali, saluran kawat, lin, jalan, batas, jurusan, perbentengan, deretan, tema. Linier dalam bidang pendidikan adalah kesesuaian antara ijazah atau jurusan yang diambil dengan mata pelajaran yang diampu atau di

${ }^{1}$ Muhammad Fadillah, Desain Pembelajaran PAUD: Tinjauan Teoritik dan Praktik, (Yogyakarta: Ar-Ruzz Media, 2012), hal.80.

${ }^{2}$ Mansur, Pendidikan Anak Usia Dini Dalam Islam, (Yogyakarta:Pustaka Pelajar,2007), hal.88-89.

Jurnal Pelang̉i Jurnal pemikiran dan penelitian pendidikan Islam anak Usia Dini 
ajarkan guru di sekolah. ${ }^{3}$

Kebijakan ini dikeluarkan oleh Kemendikbud melalui Penerbitan Peraturan Menteri Pendidikan dan Kebudayaan Nomor 46 Tahun 2016. Dengan demikian para guru harus memiliki ijazah yang sesuai dengan apa yang dijarkan di sekolah, tak terkecuali guru PAUD, ia haruslah lulusan sarjana yang memiliki kualifikasi akademik khusus di bidang anak usia dini.

Dalam Peraturan Pemerintah (PP) Nomor 19 Tahun 2005 tentang Standar Pendidik dan Tenaga Kependidikan, dinyatakan bahwa pendidik harus memiliki kualifikasi akademik dan kompetensi sebagai agen pembelajaran, sehat jasmani dan rohani serta memiliki kemampuan untuk mewujudkan tujuan pendidikan nasional. ${ }^{4}$

Kualifikasi adalah keahlian yang diperlukan untuk melakukan sesuatu, atau menduduki jabatan tertentu. Jadi kualifikasi mendorong seseorang untuk memiliki suatu keahlian atau kecakapan khusus. Kualifikasi guru dapat dipandang sebagai pekerjaan yang membutuhkan kemampuan yang mumpuni. Bahkan kualifikasi dapat dilihat dari segi derajat lulusannya. Untuk mengukur kualifikasi guru dapat ditilik dari tiga hal. Pertama, memiliki kemampuan dasar sebagai pendidik. Kualitas seperti ini tercermin dari pendidik. Kedua, memiliki kemampuan umum sebagai pengajar. Ketiga, mempunyai kemampuan khusus sebagai pelatih. ${ }^{5}$

Di dalam Undang-undang nomor 14 tahun 2005 tentang Guru dan Dosen disebutkan bahwa, istilah kualifikasi akademik yang didefinisikan sebagai ijazah jenjang pendidikan akademik yang harus dimiliki oleh guru atau dosen sesuai dengan jenis, jenjang, dan satuan pendidikan formal di tempat penugasan. ${ }^{6}$ Oleh sebab itu, Guru PAUD/TK/RA harus memiliki kualifikasi akademik pendidikan minimum diploma empat (D-IV) atau sarjana (SI) dalam bidang pendidikan anak usia dini

${ }^{3}$ Hanif Cahyo, dkk, Studi Kompetensi Guru dan Linieritas Pendidikan dalam Peningkatan Prestasi Belajar Siswa Di SD Negeri 1 Ngarip Lampung, Jurnal Pendidikan Islam, Al-Tadzkiyyah, (Volume 10. No. 2 2019), hal. 249.

${ }^{4}$ Peraturan Pemerintah (PP) Nomor 19 Tahun 2005 tentang Standar Pendidik dan Tenaga Kependidikan, Pasal (8), hal. 45.

${ }^{5}$ Yasin, Kompetensi Profesional Guru TK, (Jakarta: Rineka Cipta,2010), hal. 43

${ }^{6}$ Undang-undang Republik Indonesia No 14 Tahun 2005 tentang Guru dan Dosen, pasal 1 ayat 9. 
atau psikologi yang diperoleh dari program studi yang terakreditasi. ${ }^{7}$

Hal ini diperkuat dalam Peraturan Menteri Pendidikan dan Kebudayaan RI No. 137 tahun 2014 tentang Standar Nasional Pendidikan Anak Usia Dini tentang kualifikasi akademik guru PAUD, disebutkan bahwa:

(1a) Memiliki ijazah Diploma empat (D-IV) atau Sarjana (S1) dalam bidang pendidikan anak usia dini yang diperoleh dari program studi terakreditasi, atau, (1b) Memiliki ijazah Diploma empat (D-IV) atau Sarjana (S1) kependidikan lain yang relevan atau psikologi yang diperoleh dari program studi yang terakreditasi dan memiliki sertifikat Pendidikan Profesi Guru (PPG) PAUD dari perguruan tinggi yang terakreditasi. $^{8}$

Dengan demikian, untuk menjadi guru PAUD harus memiliki ijazah Sarjana (S1) Pendidikan Anak Usia Dini, sebab, lembaga pendidikan yang berkualitas harus dikelola oleh SDM yang berkualitas yang menempuh pendidikan sesuai dengan bidangnya, yakni memiliki standar kompetensi kualifikasi akademik. Sebab keberhasilan pendidikan anak usia dini sangat dipengaruhi oleh kualifikasi dari pendidikan guru. Sehingga, guru yang linear PAUD pada umumnya akan sangat berkompeten dibandingkan dengan guru yang tidal linear.

\section{PROBLEM LINIERITAS GURU PAUD DALAM PELAKSANAAN PEMBELAJARAN DI KBIT AL-IHSANIYAH}

\section{Kompetensi Pedagogik Guru PAUD berkualifikasi Akademik sarjana PG-PAUD dan Non PG-PAUD}

Berkenaan dengan kompetensi pedagogik guru PAUD, penulis mewawancari Baliqis Fajjarina, S.Pd selaku Kepala Sekolah KBIT AlIhsaniyah, menurutnya:

Selaku Kepala KBIT, dan yang saya ketahui, guru KBIT yang liniear memiliki kualifikasi akademik Sarjana PGPAUD memang memiliki perbedaan dengan yang berkualifikasi non PGPAUD terutama dalam

7Peraturan Menteri Pendidikan Nasional Republik Indonesia Nomor 16 Tahun 2007 tentang Standar Kualifikasi Akademik dan Kompetensi Guru.

${ }^{8}$ Peraturan Menteri Pendidikan dan Kebudayaan RI No. 137 tahun 2014 tentang Standar Nasional Pendidikan Anak Usia Dini pasal 25 ayat (1).

Jurnal Pelangỉ Jurnal pemikiran dan penelitian pendidikan Islam anak Usia Dini 
kaitan pemahamannya terjadap karakteristik peserta didik. Meskipun mereka mampu mengajar dengan baik, tetapi nampaknya belum begitu mampu. Artinya guru yang berkualifikasi PGPAUD lebih banyak variasi dan menarik dalam pembelajarannya dibandingkan yang tidak kualifikasi PGPAUD. ${ }^{9}$

Hal senada juga disampaikan oleh Nur Ayuati selaku guru di KBIT Al-Ihsaniyah, ia mengatakan:

Setelah saya menempuh Pendidikan Guru PAUD walaupun saat ini saya belum lulus, namun, saya lebih memahami betul karakteristik siswa saya dari pada sebelumnya sebelum saya kuliah PGPAUD, oleh sebab itu, saya mampu berkomunikasi dengan anak-anak lebih santai, rileks dan pengertian. Sehingga pembelajaran evaluasinya tetap bagus. ${ }^{10}$

Berikut ini beberapa dokumentasi berkenaan dengan pembelajaran yang sangat menarik dan menyenangkan saat penulis melakukan observasi di KBIT Al-Ihsaniyah.
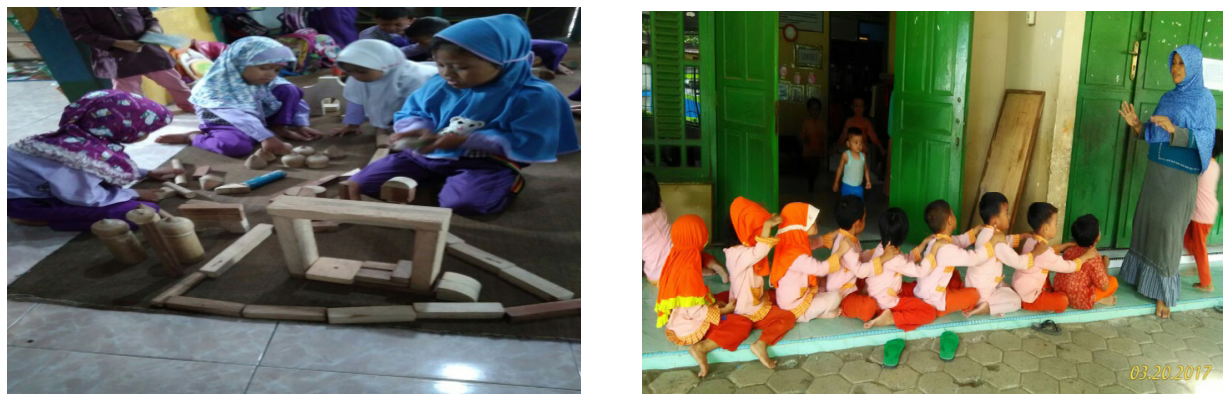

Dalam Peraturan Pemerintah No. 19 tahun 2005 pasal 28, ayat 3 disebutkan ada 4 kompetensi yang harus dimiliki oleh guru PAUD, yakni: (1) kompetensi pedagogik, (2) kompetensi kepribadian, (3) kompetensi profesional, dan (4) kompetensi sosial.

Dalam Kamus Besar Bahasa Indonesia, pedagogik berarti ilmu pendidikan; ilmu pengajaran. ${ }^{11}$ Beberapa kompetensi pedagogik yang harus dikuasai oleh guru di KBIT Al-Ihsaniyah adalah menguasai

\footnotetext{
${ }^{9}$ Wawancara dengan Baliqis Fajjarina, S.Pd selaku Kepala Sekolah KBIT Al-Ihsaniyah pada hari Kamis 28 Februari 2019 pukul 09.30 WIB di Kantor KBIT.

${ }^{10}$ Wawancara dengan Nur Ayuati selaku guru di KBIT Al-Ihsaniyah pada hari Kamis 28 Februari 2019 pukul 09.30 WIB di Kantor KBIT.

${ }^{11}$ Tim Penyusun Kamus Depdikbud, Kamus Besar Bahasa Indonesia, (Jakarta: Balai Pustaka, 1997), hal. 847.
} 
karakteristik peserta didik, dan menguasai teori pembelajaran yang baik. Hal pertama yang diterapkan dalam pembelajaran anak usia dini adalah pehaman terhadap karakteristik anak, di mana usia anak tidak sama dengan orang dewasa yang butuh perhatian dan bimbingan.

Sebagaimana yang dikemukakan oleh kepala sekolah bahwa, perbedaan guru yang berkualifikasi lulusan PAUD dan yang tidak, adalah dalam kaitan pemahamannya terhadap karakteristik peserta didik, sehingga berimbas pula pada rencana pembelajaran (RPP), walaupun secara keseluruhan guru di KBIT baik yang berualifikasi PGPAUD maupun tidak, di satu sisi pembelajarannya berjalan dengan baik dengan tahapan materi yang disampaikan sesuai dengan perkembangan peserta didik.

Dengan demikian, proses belajar merupakan interaksi komunikasi antara guru, peserta didik dalam menerima isi pesan diperlukan. Oleh sebab itu, memahami betul peserta didik adalah hal yang mutlak diperlukan agar pembelajaran berjalan efektif. Saling sharing, saling menopang dan berbagi pengalaman di antara pendidik di KBIT, baik yang sedang menempuh PGPAUD sebagaimana Nur Ayuati atau yang tidak lulusan PGPAUD, harus terus dipayakan. Memang tidak bisa dipungkiri bahwa, pemahaman terhadap kecerdasan anak secara detail dapat dipelajari saat kuliah di PGPAUD, tentu hal ini menjadi ilmu yang urjen bagi seorang guru dalam memperlakukan anak sesuai dengan pembawaan dan permainannya yang menyenangkan, sebagaimana dalam memberikan materi pembelajaran di KBIT Al-Ihsaniyah.

Selain itu, kepala sekolah di KBIT juga berperan penting dalam mengontrol kompetensi dan kualifikasi guru di KBIT, agar terjalin komunikasi dan pengertian yang baik di antara para pendidik, baik yang berkualifikasi PGPAUD maupun yang tidak.

Selanjutnya, untuk mendapatkan data berkenaan dengan problem guru yang berkualifikasi akademik NON PGPAUD, penulis juga mengadakan wawancara dengan Masitoh, S.Pd, menurutnya:

Memang saya tidak linier berlatarbelakang PGPAUD, tetapi saya S1 Bimbingan Konseling (BK), dalam hal mengatasi persoalan pembelajaran, saya sangat mampu sekali, terutama bagaimana anak agar tetap konsen, tidak ramai, berbicara sendiri-sendiri, tidak memperhatikan penjelasan guru, dan mengkondisikan agar tetap tenang dan menyenangkan dalam

Jurnal Pelang̉i Jurnal pemikiran dan penelitian pendidikan Islam anak Usia Dini 
pembelajaran. Dan setelah kondusif maka pembelajaran berjalan efektif. ${ }^{12}$ Hal tersebut dibenarkan oleh Baliqis Fajjarina, S.Pd selaku Kepala Sekolah KBIT Al-Ihsaniyah, ia menuturkan:

Bagi Masitoh, S.Pd, memang tidak menjadi problem yang berarti, sebab dia lulusan BK, yang lebih membidangi bagaimana memberikan arahan atau bimbingan kepada anak-anak, ini juga menjadi kelebihan baginya karena latarbelakangnya dari BK. ${ }^{13}$

Hal berbeda dialami oleh Rosikha selaku guru di KBIT Al-Ihsaniyah yang tidak berkualifikasi PGPAUD, ia menuturkan:

Saya tidak lulusan PGPAUD, tetapi saya terus belajar dan terus belajar dari teman-teman guru dan berbagi pengalaman dengan mereka yang lebih paham tentang karakteristik anak-anak dan bagaimana menerapkan pembelajaran yang menyenangkan bagi anak-anak. ${ }^{14}$

Berikut ini beberapa dokumentasi yang penulis dapatkan saat obervasi di KBIT Al-Ihsaniyah.
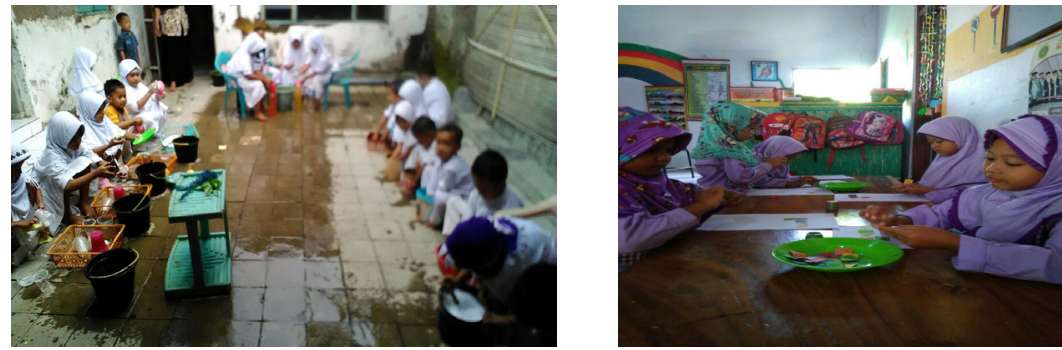

Suasana pembelajaran anak di beberapa sentra-sentra

Apa yang dikemukan oleh Masitoh dalam berupaya untuk menciptakan kondisi pembelajaran di kelas agar tetap konsen, tenang, tidak ramai, menyenangkan dan kondusif merupakan kondisi ril saat mengajar peserta didik seusia yang sekolah di KBIT, butuh perhatian dan bimbingan dan permainan yang menyenangkan. Kondisi berbeda dialami oleh Rosikha dan Eli Susanti, berbekal pengalaman mereka berdua tetap berupaya menerapkan pembelajaran yang menyenangkan.

\footnotetext{
${ }^{12}$ Wawancara dengan Masitoh, S.Pd selaku guru KBIT Al-Ihsaniyah pada hari Sabtu, 2 Maret 2019 pukul 09.30 WIB di Kantor KBIT.

${ }^{13}$ Wawancara dengan Baliqis Fajjarina, S.Pd selaku Kepala Sekolah KBIT Al-Ihsaniyah pada hari Sabtu, 2 Maret 2019 pukul 09.30 WIB di Kantor KBIT.

${ }^{14}$ Wawancara dengan Rosikha selaku guru KBIT Al-Ihsaniyah pada hari Sabtu, 2 Maret 2019 pukul 09.30 WIB di Kantor KBIT.
} 
Bakat dan kemauan guru di KBIT yang bukan lulusan PGPAUD menjadi kredit point tersendiri dalam mematahkan anggapan bahwa guru non lulusan PGPAUD tidak mampu mengajar di KBIT yang notabene anak-anak seusia 2,5 tahun sampai dengan 4 tahun, namun faktanya mereka mampu melalui itu.

Namundemikian, dalam Peraturan MenteriPendidikandan Kebudayaan RI No. 137 tahun 2014 tentang Standar Nasional Pendidikan Anak Usia Dini tentang kualifikasi akademik guru PAUD, disebutkan bahwa:

(1a) Memiliki ijazah Diploma empat (D-IV) atau Sarjana (S1) dalam bidang pendidikan anak usia dini yang diperoleh dari program studi terakreditasi, atau, (1b) Memiliki ijazah Diploma empat (D-IV) atau Sarjana (S1) kependidikan lain yang relevan atau psikologi yang diperoleh dari program studi yang terakreditasi dan memiliki sertifikat Pendidikan Profesi Guru (PPG) PAUD dari perguruan tinggi yang terakreditasi. ${ }^{15}$

Walaupun secara ketrampilan dan keahlian berbekal pengalaman mereka mampu mengajar di KBIT Al-Ihsaniyah secara baik, tetapi peraturan tetaplah peraturan, maka langkah sangat bijak ketika para pendidik yang belum atau bukan lulusan PGPAUD untuk melanjutkan pendidikannya, selain itu, mereka akan mendapatkan pengalaman lebih untuk menjadi pendidikan anak usia dini.

\section{a. Kompetensi Profesional Guru PAUD berkualifikasi Akademik sarjana PG-PAUD dan Non PG-PAUD}

Untuk mendapat data tentang kompetensi profesional di KBIT AlIhsaniyah, penulis mewawancarai Baliqis Fajjarina, S.Pd selaku kepala sekolah, ia menuturkan:

Guru-guru kami di KBIT, sebenarnya dari sisi penguasaan materi sudah mampu mengembangkan dan mengemas alat permainan yang menarik untuk mendukung pembelajaran. ${ }^{16}$

Senada dengan Balqis, Nur Ayuati selaku guru di KBIT Al-Ihsaniyah menuturkan:

${ }^{15}$ Peraturan Menteri Pendidikan dan Kebudayaan RI No. 137 tahun 2014 tentang Standar Nasional Pendidikan Anak Usia Dini pasal 25 ayat (1).

${ }^{16}$ Wawancara dengan Baliqis Fajjarina, S.Pd selaku Kepala Sekolah KBIT Al-Ihsaniyah pada hari Sabtu, 2 Maret 2019 pukul 09.00 WIB di Kantor KBIT.

Jurnal Pelang̉i Jurnal pemikiran dan penelitian pendidikan Islam anak Usia Dini 
Saat di kelas, saya menggunkan berbagai alat permainan, seperti jamujamuan, ular tangga yang melibatkan aspek fisik dan kognitif. Selain itu, bahasa yang saya gunakan agar peserta didik dapat berkembang, saya setiap kali bersama-sama anak-anak di kelas menyampaiakan materi dengan berbagai bahasa, kadang Indonesia, kromo, bahkan saya masukan juga inggris. ${ }^{17}$

Terkait dengan penggunaan alat bermain yang dapat menunjang pembelajaran, Masitoh, S.Pd, selaku guru di KBIT Al-Ihsaniyah menambahkan:

Ketika di kelas, saya menggunakan alat permain sebagai media agar anak merasa menjadi senang dan terhibur. Misalnya permainan boneka untuk mengenalkan bagian tubuh tertentu, bermain mobilmobilan untuk mengenalkan kepada peserta didik tentang alat transportasi darat. Namun demikian saya tetap menyesuaikan tahapan perkembangan peserta didik. ${ }^{18}$

Profesionalisme guru PAUD juga ditunjukan dengan penguasaanya di bidang teknologi dan informasi sebagai media pengembangan diri. Di antaranya dikemukakan oleh Nur Ayuati selaku guru di KBIT AlIhsaniyah, ia menuturkan:

Problem yang harus saya pecahkan adalah bagaimana memanfaatkan IT untuk pembelajaran dan dapat berkomunikasi dengan orang tua, guru oleh sebab itu, saya menjalin kumunikasi melalui group Whatsapp, dan itu terus saya upayakan secara maksimal. ${ }^{19}$

Terkait dengan pemanfaatan tekonologi dan informasi, Masitoh, S.Pd, juga menuturkan:

Laptop setiap hari saya bawa, karena memudahkan untuk menunjang pembelajaran, termasuk digunakan untuk memasukan nilai anak, membuat RPPH, dan menampilan gambar atau film di LCD Proyektor. ${ }^{20}$

\footnotetext{
${ }^{17}$ Wawancara dengan Nur Ayuati selaku guru di KBIT Al-Ihsaniyah pada hari Sabtu, 2 Maret pukul 10.00 WIB di Kantor KBIT.

${ }^{18}$ Wawancara dengan Masitoh, S.Pd selaku guru KBIT Al-Ihsaniyah pada hari Sabtu, 2 Maret 2019 pukul 09.30 WIB di Kantor KBIT.

${ }^{19}$ Wawancara dengan Nur Ayuati selaku guru di KBIT Al-Ihsaniyah pada hari Jumat 15 Maret 2019 pukul 09.00 WIB di Kantor KBIT.

${ }^{20}$ Wawancara dengan Masitoh, S.Pd selaku guru KBIT Al-Ihsaniyah pada hari Jumat 15 Maret 2019 pukul 09.00 WIB di Kantor KBIT.
} 


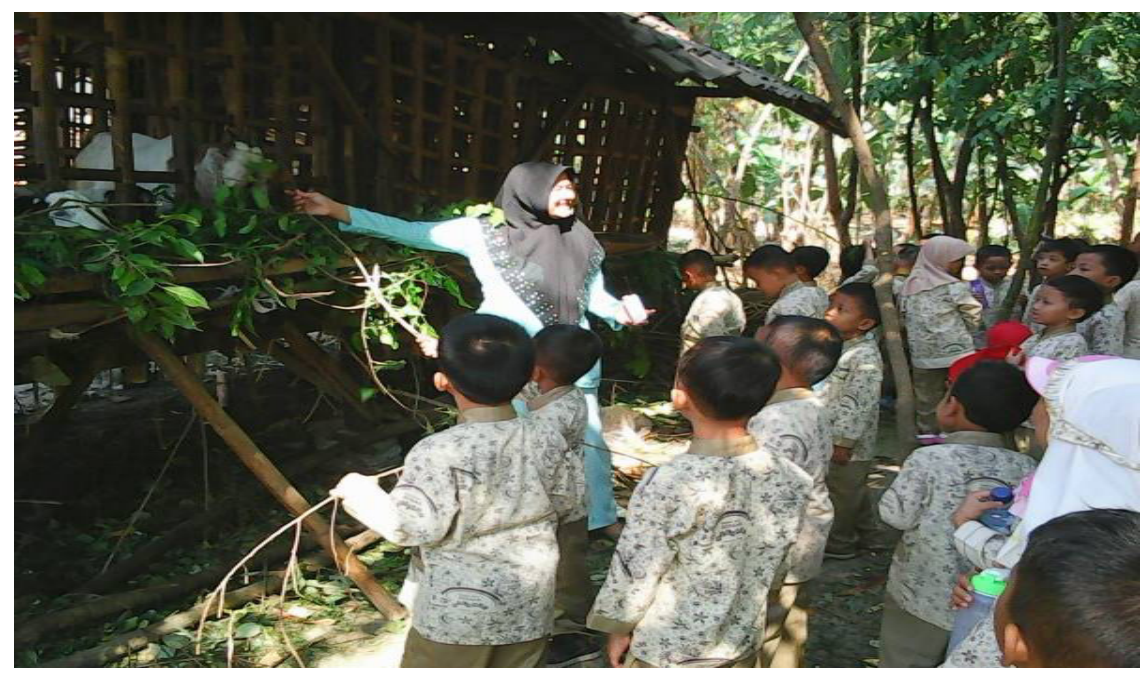

Berikut ini beberapa dokumentasi yang penulis dapatkan saat obesrvasi di KBIT Al-Ihsaniyah.

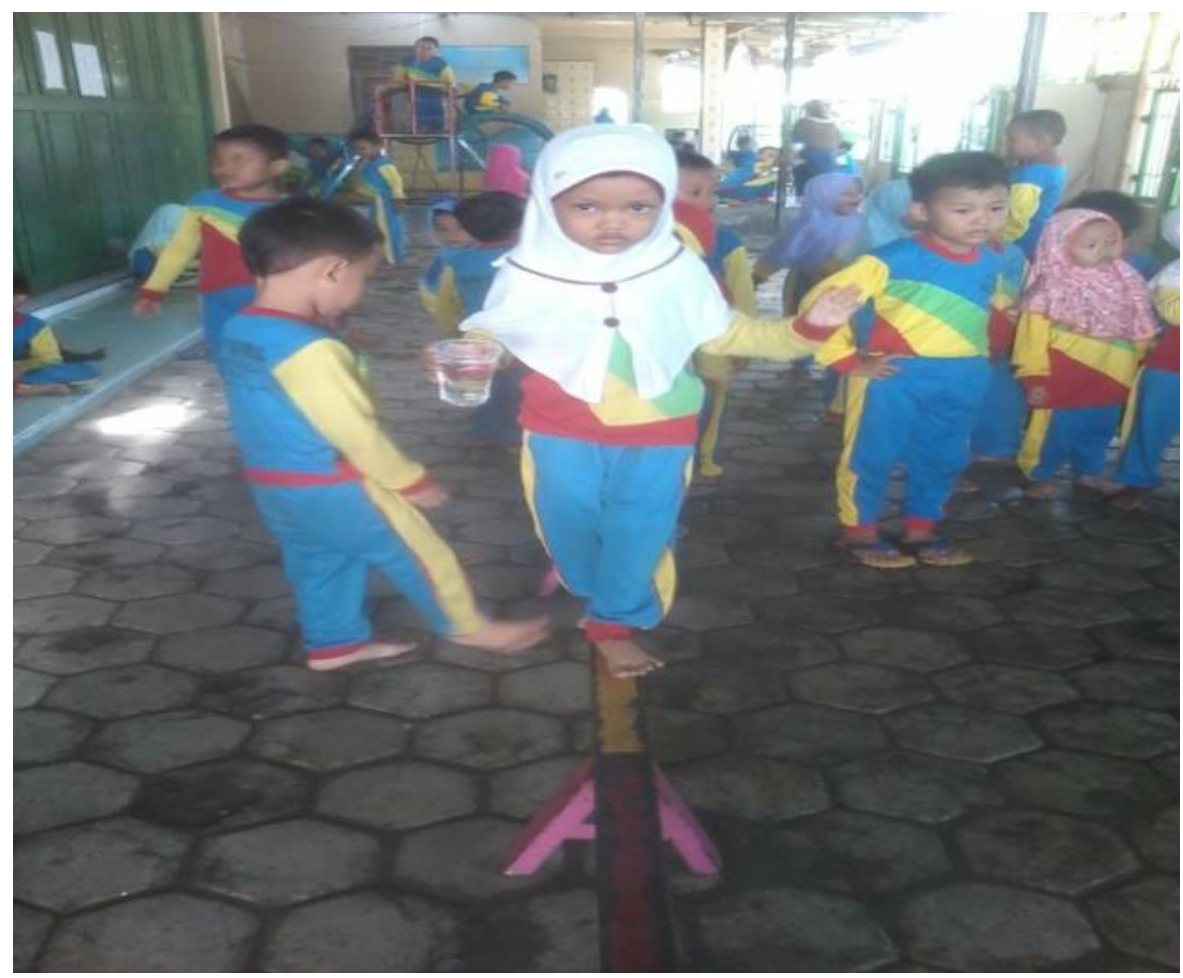

Anak-anak diajak belajar diluar lingkungan untuk observasi ke kandang kambing 


\section{Anak-anak sedang melakukan kegiatan motorik kasar}

Dari hasil wawancara dengan beberapa guru di KBIT AlIhsaniyah berkenaan dengan kompetensi profesional guru PAUD disimpulkan ada 3, yakni (1) menguasai materi pelajaran yang diampu dengan menggunakan berbagai permainan yang menarik (2) mampu mengembangkan materi sesuai dengan karakteristik peserta didik, dan (3) memanfaatkan teknologi dan informasi dalam pembelajaran.

Pertama, guru di KBIT Al-Ihsaniyah secara umum, baik yang sedang menempuh S1 PGPAUD atau yang belum, telah sesuai dengan standar komptensi profesional guru. Hal ini dapat dilihat dari berbagai metode yang diterapkan guru di KBIT saat memberikan materi kepada peserta didik. Misalnya dalam penggunaan alat permainan yang kreatif dan dapat disenangi oleh anak, sehingga pembelajaran sesuai dengan harapan.

Hal ini merujuk pada Peraturan Menteri Pendidikan Nasional Indonesia Nomor 16 Tahun 2007 Tentang Standar Kualifikasi Akademik Dan Standar Kompetensi Guru, disebutkan bahwa, “indikator dari menguasai materi, struktur, konsep, dan pola pikir keilmuan yang mendukung mata pelajaran yang diampu yaitu menguasai konsep ilmu dasar (matematika, sains, bahasa, pengetahuan sosial, agama, seni, pendidikan jasmani, kesehatan dan gizi), Menguasai penggunaan berbagai alat permainan untuk mengembangkan aspek fisik, kognitif, sosial-emosional, nilai moral, sosial budaya dan bahasa dan menguasai berbagai alat permainan anak sebagai media untuk mengajar".

Kedua, dalam mengembangkan materi, guru di KBIT telah berhasil menyesuaikannya dengan perkembangan peserta didik, hal ini terlihat dari cara guru menyusun RPPH, dan memahami kemajuan peserta didik setelah melakukan pembelajaran. Hal ini dapat dijadikan evaluasi, apakah peserta didik sudah mencapai indicator pencapaian atau justru malah sebaliknya. Selain itu, guru di KBIT terlepas dari linieritas guru PAUD dan tidaknya telah mampu mengolah materi dan mengembangkan materi menjadi pembelajaran yang kreatif dan menyenangkan seperti mendongeng, bernyanyai dan bertepuk tangan. Hal ini menyebabkan pembelajaran semakin diminati anak dan tidak membosankan.

Ketiga, penggunaan media pembelajaran yang sesuai dengan perkembangan zaman, seperti LCD proyektor di KBIT Al-Ihsaniyah 
menunjukan bahwa, guru di KBIT telah memenuhi standar profesional guru PAUD untuk memanfaatkan teknologi dan informasi untuk pembelajaran yang efektif, walaupun masih banyak yang perlu dibenahi di masa-masa yang akan datang. Seperti pengadaan Laptop lebih dari satu, atau LCD proyektor bisa ditambah, dan materi-materi pembelajaran yang perlu dilengkapi. Selain itu, jalinan komunikasi dengan pihak orang tua juga perlu dipertahankan untuk mendapatkan informasi-informasi yang cepat dan valid dalam pembelajaran di KBIT Al-Ihsaniyah.

\section{Upaya Pengembangan Linieritas Guru PAUD di KBIT Al-Ihsaniyah}

Dalam upaya pengembangan linieritas guru PAUD di KBIT AlIhsaniyah, terdapat 4 kebijakan yang diterapkan yakni: (1) linieritas guru PAUD dalam proses seleksi guru di KBIT, (2) pembinaan melalui program magang/mengabdi terlebih dulu, (3) mengikuti diklat, seminar, atau pelatihan kompetensi pendidik PAUD, (4) sharing berbagi pengetahuan.

Pertama, dari hasil wawancara dengan kepala sekolah KBIT AlIhsaniyah, bahwa, "walaupun itu sulit, tetapi ada usaha yang sudah kami lakukan di KBIT dalam proses seleksi guru yang mau mengajar di KBIT alIhsaniyah haruslah yang linier". Langkah ini perlu diapresiasi walaupun memang kesulitan untuk mencari guru yang lulusan S1 PGPAUD sebagaimana yang dialami oleh KBIT Al-Ihsaniyah sendiri, hal ini bisa dilihat dari data jumlah guru yang memenuhi standar kualifikasi guru PAUD, terdapat satu guru yang sedang melakukan perkuliahan PGPAUD.

Namun demikian, problem linieritas yang dialami oleh lembagalembaga Pendidikan Anak Usia Dini tak terkecuali di KBIT Al-Ihsaniyah hampir merata. Usaha dan upaya yang diharapkan dari kepala sekolah menjadi kebijakan yang bermuara pada peningkatan Sumber Daya Manusia (SDM), sebab dengan SDM yang berkualitas, pendidikan yang unggul dapat tercapai. Maka kesempatan untuk melanjutkan S1 PGPAUD di KBIT Al-Ihsaniyah bagi yang berkulifikasi menjadi program yang terus diupayakan dan dilanjutkan.

Oleh karena itu, pendidik yang berkualitas memiliki kekuatan empat kompetensi dasar yakni kompetensi pedagogis, kepribadian, sosial dan profesioanal. ${ }^{21}$

${ }^{21}$ Suyadi, Managemen PAUD TPA-KB-TK/-RA Mendirikan, Mengelola dan Mengembangkan PAUD, (yogyakarta: Pustaka Pelajar, 2011) hal.139.

Jurnal Pelang̉i Jurnal pemikiran dan penelitian pendidikan Islam anak Usia Dini 
Hal ini sebagaimana yang diamatkan dalam Peraturan Pemerintah (PP) Nomor 19 Tahun 2005 tentang Standar Pendidik dan Tenaga Kependidikan, dinyatakan bahwa pendidik harus memiliki kualifikasi akademik dan kompetensi sebagai agen pembelajaran, sehat jasmani dan rohani serta memiliki kemampuan untuk mewujudkan tujuan pendidikan nasional. ${ }^{22}$

Kedua, program magang atau ngabdi sebelum resmi menjadi guru PAUD di KBIT Al-Ihsaniyah diterapkan adalah dalam upaya persiapan awal sebagai pelatihan pendididikan guru yang disupervisi oleh kepala sekolah, hal ini dimaksudkan agar memiliki kemampuan dalam melaksanakan pembelajaran yang baik.

Ketiga, kewajiban mengikuti seminar, diklat dan pelatihan-pelatihan kompetensi guru PAUD sangat diperlukan untuk meningkatkan kompetensi yang dimiliki oleh guru di KBIT. Dengan mengikuti berbagai kegiatan tersebut, kemampuan dan ketrampilan mereka berkenaan dengan seluk beluk PAUD akan berkembang, seperti bagaimana mengelola, merencanakan, dan mengevaluasi pembelajaran yang sesuai dengan tahapan perkembangan anak serta oembelajaran yang bermakna dan menarik.

Dengan meningkatnya kemampuan guru di KBIT Al-Ihsaniyah pada akhirnya akan berkontribusi terhadap peningkatan kualitas pendidikan di KBIT Al-Ihsaniyah dan mampu melahirkan SDM yang unggul dan bermutu.

Keempat, saling berbagi (sharing) ilmu dan pengalaman di antara guru di KBIT Al-Ihsaniyah merupakan bagian dari penilaian bersama atas kinerja masing guru di KBIT. Kegiatan ini bertujuan agar masingmasing mendapat masukan, kritik ataupun saran, baik yang berkenaan dengan pengelolaan dan pengembangan aspek ketrampilan peserta didik, sehingga menjadi bahan evaluasi untuk perbaikan pembelajaran selanjutnya.

Linieritas dalam konteks ini sebagaimana disebutkan dalam Peraturan Menteri Pendidikan dan Kebudayaan RI No. 137 tahun 2014 tentang Standar Nasional Pendidikan Anak Usia Dini tentang kualifikasi

\footnotetext{
${ }^{22}$ Peraturan Pemerintah (PP) Nomor 19 Tahun 2005 tentang Standar Pendidik dan Tenaga Kependidikan, Pasal (8).
} 
akademik guru PAUD haruslah lulusan sarjana yang memiliki kualifikasi akademik khusus di bidang anak usia dini. Maka secara garis besar, pengembangan linieritas secara formal hanya akan tercapai manakala guru di KBIT Al-Ihsaniyah melanjutkan kembali kuliah S1 PGPAUD, namun upaya yang dilakukan dari KBIT Al-Ihsaniyah sudah berjalan dengan baik, walaupun baru tercatat 1 guru yang masih terdaftar kuliah S1 PGPAUD dan guru yang merupakan lulusan Bimbingan Konseling.

Dengan usaha dan upaya yang berkesinambungan, tentu hal ini menjadi modal penting bagi lembaga pendidikan untuk memenuhi kuota linieritas guru PAUD. Beberapa program dan kegiatan yang sudah dilakukan oleh KBIT Al-Ihsaniyah akan menjadi jembatan menuju linieritas guru-guru di KBIT Al-Ihsaniyah.

\section{KESIMPULAN}

Problem linieritas guru PAUD dalam melaksanakan pembelajaran di KBIT Al-Ihsaniyah mencakup dua kompetensi, yakni kompetensi pedagogik dan profesional yang berkualifikasi akademik S1 PGPAUD dan non kualifikasi.

Beberapa guru yang sedang menempuh S1 PGPAUD dan yang lulusan Bimbingan Konseling dalam konteks pedagogik memiliki kemampuan yang berbeda dengan guru selain keduanya terutama dalam pemahaman karakteristik peserta didik. Namun demikian, tidak semua yang tidak kualifikasi PGPAUD tidak dapat mengajar dengan baik, sebab pada kenyataannya masing-masing guru bahu membahu menutup celah yang kosong dan berupaya untuk menjadikan pembelajaran di KBIT berjalan baik, menarik dan menyenangkan sehingga tercapai hasil pendidikan yang optimal.

Terdapat tigal hal capaian profesional guru di KBIT Al-Ihsaniyah, yakni:(1) menguasai materi pelajaran yang diampu dengan menggunakan berbagai permainan yang menarik (2) mampu untuk mengembangkan materi pembelajaran sesuai dengan tumbuh kembang peserta didik, dan (3) kemampuan untuk memanfaatkan media pembelajaran dengan teknologi, informasi dan komunikasi.

Beberpa upaya yang dikembangkan di KBIT Al-Ihsaniyah dalam menanggulangi problem linieritas guru PAUD, maka beberapa kebijakan

Jurnal Pelangi Jurnal pemikiran dan penelitian pendidikan Islam anak Usia Dini 
dan program dijalankan, di antaranya ialah: (1) melakukan proses seleksi linieritas guru PAUD, (2) program magang/mengabdi terlebih dulu bagi yang diterima di KBIT Al-Ihsaniyah, (3) mengikutsertakan pada kegiatan diklat, seminar, tentang kompetensi pendidik PAUD, dan (4) menjalin komunikasi dengan selalu sharing berbagi pengalaman dan pengetahuan.

\section{REFERENSI}

Cahyo, Hanif, dkk, Studi Kompetensi Guru dan Linieritas Pendidikan dalam Peningkatan Prestasi Belajar Siswa Di SD Negeri 1 Ngarip Lampung, Jurnal Pendidikan Islam, Al-Tadzkiyyah, Volume 10. No. 2019. Fadillah, Muhammad, Desain Pembelajaran PAUD: Tinjauan Teoritik dan Praktik, Yogyakarta: Ar-Ruzz Media, 2012.

Mansur, Pendidikan Anak Usia Dini Dalam Islam, Yogyakarta:Pustaka Pelajar,2007.

Peraturan Pemerintah (PP) Nomor 19 Tahun 2005 tentang Standar Pendidik dan Tenaga Kependidikan.

Peraturan Menteri Pendidikan dan Kebudayaan RI No. 137 tahun 2014 tentang Standar Nasional Pendidikan Anak Usia Dini.

Peraturan Menteri Pendidikan Nasional Republik Indonesia Nomor 16 Tahun 2007 tentang Standar Kualifikasi Akademik dan Kompetensi Guru.

Permendiknas Nomor 16 Tahun 2007: Standar Kualifikasi Akademik.

Suyadi, Managemen PAUD TPA-KB-TK/-RA Mendirikan, Mengelola dan Mengembangkan PAU, yogyakarta: Pustaka Pelajar, 2011.

Undang-undang Republik Indonesia No.14 Tahun 2005 tentang Guru dan Dosen.

Undang-Undang Republik Indonesia No.20 Tahun 2003.

Yasin, Kompetensi Profesional Guru TK, Jakarta: Rineka Cipta,2010. 